\title{
Siirtymätila aikuiskoulutuksen itseymmärryksen välineenä
}

\begin{abstract}
Työn arjessa tehdään työtä tavalla ja olosuhteissa, jotka eivät kirjoittajan mukaan näytä mahdollistavan tietoista toiminnasta oppimista. Jotta oppiminen työssä ja työstä olisi mahdollista, työntekijän on luotava itselleen psyykkisiä ja fyysisiä siirtymätiloja, joissa toiminnan monipuolinen pohdinta ja arviointi mahdollistuvat.
\end{abstract}

Koulutusta käsitellään artikkelissa tällaisena siirtymätilana. Aikuiskoulutukselle tarjoutuu ainakin kaksi rinnakkaista strategiaa kytkeytyä muutokseen. Toinen strategia pyrkii kytkemään koulutuksen osaksi työorganisaatioiden toiminnan välittömiä kehittämistarpeita. Toinen toimintastrategia hakee

koulutuksellisen siirtymätilatyöskentelyn avulla mahdollisuuksia työorganisaatioiden vaihtoehtoisten muutostarpeiden ja suuntien pohdintaan.

Koulutuksellinen siirtymätila luo edellytykset kokemuksen vaihdolle, joka ylittää ahtaat organisaatio- ja ammattirajat.

Artikkelin tavoitteena on hahmotella aikuiskoulutuksen ammattityöhön sellaisia ajattelun välineitä, joiden avulla työtä tekevä suunnittelija voi oivaltaa oman työnsä mielen ja merkityksen suhteessa työelämän kehittämiseen ja tutkimukseen.
Suomalaisessa koulutuskentässä ja työelämässä on meneillään murros, jonka ymmärtämiseksi aikuiskoulutukseen erikoistuneet yksiköt ja niissä työskentelevät tarvitsevat jäsentäviä käsitteitä ja teoreettisen ajattelun välineitä. (ks.Valkama 1991, 3435) Koulutusyksikköjen on pystyttävä hahmottamaan suhdettaan ympäristöönsä entistä syvällisemmin.

Tässä artikkelissa itseymmärryksen näkökulmaa kehitellään erityisesti yliopistollisen täydennyskoulutuksen kannalta, jonka rooli tutkimuksen ja työelämän kehittämisen sillanrakentajana edellyttää pohdintaa.

Markkinointihenkisesti paketoitujen kurssikokonaisuuksien tuottamisen strategian rinnalla koulutuskeskuksissa elää pitkäjänteisemmän tutkimus- ja koulutusyhteistyön pyrkimyksiä, jotka hakevat yhteyksiä työorganisaatioiden sisäisiin kehittämisprosesseihin. Koulutushankkeet lähenevät otteeltaan organisaatioiden kehittämistä, projektikonsultointia, laatupiiriä tai työnohjausta. Oleellista näissä hankkeissa on se, että niissä pyritään etenemään koulutuksen tarvitsijoiden lähtökohdista. Kysymykseksi asettuu, miten opetus saadaan muutettua oppimiseksi, joka palvelee organisaatioiden ja niissä toimivien ihmisten tarpeiden mukaisia muutoksia. Koulutuksen sisältö pyrkii lähtemään liikkeelle osanottajien arkitodellisuudesta ja työtehtävistä arjessa.(Moilanen 1990, $7-11)$

Tämä kehitys suuntaa koulutusorganisaatioita osanottajaperustaisen yhteistyön sijasta työorganisaatiokohtaiseen yhteistyöhön. Yksilöiden sijasta pyritään kohtaamaan ryhmiä ja rakenteita, joita lähestymistavasta riippuen nimitetään yhteisöiksi, työorganisaatioiksi tai toimintajärjestelmiksi. Hankkeet näyttävät edustavan usein yhtei- 
söllisyyttä, joka ei näkyvästi nosta käsittelyyn työpaikkatason vallankäyttöä. (ks. Morgan 1986, 187)

Mikä on yliopistollisen täydennyskoulututuksen rooli tässä kehittämistyössä? Mikä on keskusten työn kohde tai toiminta-ajatus? Tämän tyyppisten yleistysten tekeminen edellyttäisi systemaattista toimintamuotojen ja koulutusten analysointia. Tässä artikkelissa pelkistän kuitenkin tarkoituksellisesti kaksi vaihtoehtoista ajattelukehystä aikuiskoulutuksellisen toiminnan itseymmärryksen peileiksi.

Erik Arnkil (1991, 26-37) on käyttänyt töissään peili-metaforaa. Hän kuvaa sosiaalityöhön kohdistuvaa tutkimusta, jonka aikana sosiaalityöntekijät tarkentavat tutkijoitten avustuksella suhdettaan työnsä kohteeseen. Yhteistoiminnallisen työskentelyn kautta rakennetaan peilejä, jotka auttavat näkemään työn yhteyksiä rinnakkaistyöprosesseihin. Peilit sisältävät hypoteeseja ja uusia käsitteitä, jotka voivat kääntää havaitsijan katseen refleksiiviseksi. Uusi käsite voi auttaa näkemään oman työn toimintana, jolla on toistuvia käytäntöjä ja rakenteita, joita aikaisemmin ei ole havainnut.

Mielestäni aikuiskoulutuksessa tulisi myös rakentaa peilejä, jotka auttavat näkemään paremmin toiminnan mielen ja merkityksen. Silloin tarvitaan myös uusia näkökulmia avaavia käsitteitä, jotka auttavat analysoimaan koulutusta yhteiskunnallisissa ja kulttuurisissa yhteyksissään.

Aikuiskoulutukselle tarjoutuu ainakin kaksi rinnakkaista strategiaa kytkeytyä meneillä olevaan muutokseen. Tällä hetkellä koulutustoiminnan peiliksi tarjoutuu kebittämisen peili, joka pyrkii kytkemään aikuiskoulutustoiminnan tiukasti osaksi työorganisaatioiden toiminnan kehittämistä. Tällä korostetaan välttämättömyyttä tutkia ja kehittää ihmisten ajattelua ja toimintaa luonnollisessa ympäristössään. (esimerkiksi Miettinen 1990, 189)

Toinen aikuiskoulutustoiminnalle mahdollinen toimintastrategia ja itseymmärrystä luova peili lähtee liikkeelle siirtymätilatyöskentelystä. Mielestäni siirtymätilakäsitteen (ks. Hirschhorn-Gilmore 1989) avulla voidaan määrittää aikuiskoulutuksen verkostoja ja siltoja rakentavaa työtä tarkemmin. Siirtymätilan käsitettä käytän tässä artikkelissa vielä ehdotelmanomaisesti ja kokeillen. Mielestäni käsitteen avulla voidaan avata kiinnostavia näköaloja aikuiskoulutuksen kehittämiselle.

\section{Siirtymätila käsitteenä}

Tarkasteluni lähtee liikkeelle siirtymätilan käsitteestä, jonka hedelmällisyys perustuu itse asiassa eräänlaiseen käänteiseen oivallukseen. Työyhteisöjen sisäiseen kehittämiseen kytkeytyvän aikuiskoulutustoiminnan sijasta korostan ulkopuolisen koulutustoiminnan merkitystä. Lähden liikkeelle ajatuksesta, jonka mukaan olemassa olevalle aikuiskoulutusverkostolle on ominaista jatkuva, osittainen ulkopuolisuus. Ulkopuolisuus mahdollistaa uutta hakevan ja vaihtoehtoisia toiminta- ja ajattelutapoja vertailevan tarkastelun suhteessa toimintajärjestelmien rakenteisiin. Koulutusohjelmilla voi siirtymätiloina olla tärkeä kokemusta laajentava ja kehitystä virittävä rooli.

Siirtymätilan tärkeyden perustelu löytyy huomiosta, jonka mukaan työn arjessa tehdään työtä tavalla ja olosuhteissa, jotka eivät näytä mahdollistavan tietoista toiminnasta oppimista. Jotta oppiminen työssä ja työstä olisi mahdollista, on työntekijän luotava itselleen psyykkisiä ja fyysisiä siirtymätiloja, joissa toiminnan monipuolinen pohdinta ja arviointi mahdollistuu. Kysymys on välittömän tekemisen "työntäminen" tarkasteltavaksi välimatkan takaa, jonka kautta tekemisen mielen hakeminen mahdollistuu. (Hirschhorn-Gilmore 1989)

Siirtymätila sijaitsee työelämän todellisuuden ja itse koulutuksen kautta luodun todellisuuden välissä. Tässä tilassa ajatukset ja tuntemukset voi tuoda esiin turvallisissa kehyksissä. Siirtymätilassa voivat ydinkysymykset nousta pintaan voimakkaasti, virittäen oleellisia baasteita, joita kohdataan muutettaessa periytyvää kulttuuria. (Hirschhorn-Gilmore 1989, 230-232)

Siirtymätilan käsite ei sulje aikuiskoulutuksellista toimintaa yhteiskunnan ulkopuoliseksi "hyödyttömäksi" harrastukseksi, kuten helposti voisi käsitteen alustavan määrittelyn perusteella päätellä. Yhteiskunta ja työelämä ovat läsnä siirtymätilatyöskentelyn keskustelussa ja analyyseissä. Työssä oppimisen ja työtoiminnan vaihtoehtojen hahmottelun ehtona on tilapäinen vapautuminen työelämän taloudellisen imperatiivin määrittämän arkipäivän puristuksesta. Hirschhorn ja Gilmore kytkevät siirtymätilassa tapahtuvan oppimisen työorganisaatioiden muutosprosessien ongelmanmäärittelyvaiheeseen. Heidän mukaansa työorganisaatioissa voidaan edetä muutosprosesseissa vasta sitten, kun ensin määritellään joitakin on- 
gelmia, joita voidaan aidosti lähteä ratkaisemaan yhteistyössä.

Siirtymätilaa muistuttava rinnakkaiskäsite löytyy Arnkililta, joka on käyttänyt toisessa yhteydessä rajasysteemin käsitettä. (Rajasysteemikäsitteen Arnkil on omaksunut Seikkulan ja Sutelan 1989 töistä.) Arnkil tutkii rajasysteemin käsitteen avulla viranomaisyhteistyötä. Hän korostaa, että tutkittava toiminta on hedelmällisempää asettaa vaihtosuhteisiinsa ja tutkia sitä osana niitä välitason systeemejä, joita se on mukana muodostamassa. Keskinäinen vaihto merkitsee sitä, että välitason systeemiin kulkeutuu tuntuvasti aineksia alatason systeemeistä (ks. Arnkil 1990, 5).

Sovellan Arnkilin esittelemää rajasysteemin käsitettä yliopistolliseen täydennyskoulutukseen. Alasysteemejä tässä koulutuksellisessa välitason systeemissä ovat asiantuntijatehtävissä toimivat ammattilaiset, jotka tuovat koulutukselliseen siirtymätilaan mukanaan oman ammatillisen työorientaationsa mukaisia tavoitteita, tarpeita ja odotuksia. Nämä tavoitteet, tarpeet ja odotukset heijastavat samalla myös osanottajien työorganisaatioiden (alatason systeemi) odotuksia ja muutoshaasteita. Koulutukselliseen siirtymätilaan kytkeytyvät tutkijat (alasysteemi) tuovat tilaan mukanaan myös omat intressinsä ja tapansa toimia ja ajatella.

Siirtymätilassa syntyy yhteistyön muotoja, jotka eivät luonnehdi yksin minkään alatason systeemin (ammattilaiset, työorganisaatiot, yliopistollinen tutkijayhteisö) ominaisuuksia. Eri osapuolten sisäistämät ennakoinnit, työskentelytottumukset ja työkulttuurit muokkaavat työskentelyä siirtymätilassa. Siirtymätilan käsitteeseen sisältyy samoja aineksia kuin Scheinin nimeämiin seminaarien "kulttuurisaarekkeisiin", joissa työskentely muokkautuu erilaisten vihjeitten kautta. (ks. Schein 1987, 200). Kysymys on yhteisen ja jaetun työskentelykohteen muodostamisprosessista, jonka onnistumisen ehtona on se, että kaikki osapuolet tuovat prosessiin omia näkökulmiaan tutkittavista ja käsiteltävistä todellisuuden ilmiöistä.

\section{Asiantuntijuuden kehittämisen haasteet}

Siirtymätilan määrittelyn kannalta on tärkeää vielä analysoida siirtymätilan suhdetta kehitettävään toimintaan. On perusteltava, miksi siirtymätiloja tarvitaan. On myös analysoitava, mikä on ul- kopuolisten koulutusfoorumien suhde työorganisaatioiden kehittämistavoitteisiin ja päämääriin. Tässä artikkelissa valitun näkökulman mukaisesti on kysymys siitä, miten yliopistollinen täydennyskoulutustoiminta vastaa akateemisesti koulututettujen asiantuntijoiden kompetenssin kehittämisen haasteisiin

Kiihtyvän yhteiskunnallisen murroksen oloissa (tästä enemmän artikkelissani, joka julkaistaan KTL:n sarjassa syksyllä 1992 aikuiskasvatuksen II tutkijatapaamisen kokoomajulkaisussa) koulutuskeskukset kohtaavat uudenlaiset, asiantuntijatyön kehittämisen haasteet. Koulutuskeskukset joutuvat tulkitsemaan omaa suhdettaan esimerkiksi julkisen sektorin saneeraamiseen ja ohjausjärjestelmien muutoksiin. Miten kehittää ja täydentää asiantuntemusta, johon kohdistuvat enenevässä määrin ammatillisia rajoja ylittävät osaamisen paineet.

Selkeästi spesialisoituvan professiostrategian rinnalle on työorganisaatioissa noussut tarve kehittää asiantuntemusta, joka auttaa hallitsemaan kokonaistoimintaa työorganisaatiotasolla. Syvenevä erikoistuminen nähdään yhä useimmin kokonaistyöprosessin hallinnan sekä joustavan tehtävien uudelleen määrittelyn esteenä nopeasti muuttuvassa toimintaympäristössä.

Siirtymä on merkinnyt $\mathrm{mm}$. ammattien roolin uudelleenjäsentämistä. Toimintaympäristön muutokset edellyttävät rajatun ammatillisen ongelmanratkaisun sijasta asiantuntijoilta kykyä nähdä todellisia vaihtoehtoja työorganisaatioitten muutosprosessien suuntaamisessa. Kysymys on siitä, millaisen tiedon perusteella luodaan työkäytäntöihin välttämättömät vaihtoehdot. (ks. CrozierFriedberg 1980, 229).

Asiantuntijatehtävissä toimivien työorganisaatioiden ydinhenkilöiden on tehtävä tulkintaa muuttuvista olosuhteista. Miten työorganisaation olisi suuntauduttava uudella tavalla ympäröivään todellisuuteen?

Yliopistollinen täydennyskoulutus joutuu ottamaan kantaa joustavuuskeskusteluun ja ammattien roolin uudelleenjäsentämiseen. Kysymys on hyvin ristiriitaisesta asiasta. Työorganisaatioissa on pyrkimyksiä toisaalta supistaa ammatillista autonomiaa ja liikkuma-alaa. (ks. esimerkiksi Morgan 1986, 169). Toisaalta asiantuntijatehtävissä toimivat henkilöt haluavat säilyttää ja lisätä omaa tiedollista etumatkaansa lisäämällä päätösvaltaansa omaan työhönsä liittyviin asioihin. (ks. esimerkiksi Filander ym. 1990,17). 
Panhelaisen (1991) mukaan täydennyskoulutustoiminnassa on vallinnut työorganisaation ja korkeasti koulutetun professionalistin välinen osittain julkilausumaton sosiaalinen sopimus molemminpuolisesta hyödystä, jota voidaan edistää täydennyskoulutuksen avulla. (Panhelainen 1991, 13). Missä määrin tilanne muuttuu tulevina vuosina? Todennäköisesti rahallisista satsauksista odotetaan kiristyvän talouden oloissa yhä selkeämpää tulosta, mikä kaventaa liikkuma-alaa siirtymätilojen sisällä.

Asiantuntijat toimivat organisaatioissa avainvaikuttajina, eräänlaisina tiedonkulun portinvartioina (ns. gatekeepers ks. Grozier - Friedberg 1980, 82, myös Morgan 1986, 167). He käyttävät työorganisaatioissa valtaa juuri avaamalla ja sulkemalla kommunikaatiokanavia ja tulkitsemalla, tekemällä yhteenvetoja, analysoimalla ja muokkaamalla tietoa, jolla valmistellaan työorganisaatioiden päätöksentekoa ja muutosprosesseja. (ks. Morgan 1986, 167). Asiantuntijoiden vallankäytön muoto liittyy ensisijaisesti ongelmien määrittelyyn.

Yliopistolliset täydennyskoulutuskeskukset ovat vastaamassa haasteeseen, miten kehittää kvalifikaatioita, jotka liittyvät enemmän tulevaisuuden luomiseen kuin olemassa olevien käytäntöjen toistamiseen tai monistamiseen. Asiantuntijatyön kehittämisen kannalta on tärkeää tutkia, onko mahdollista rakentaa oppimisareenoita, jotka antavat aineksia uusia toimintakäytäntöjä kypsyttävien toimintavaihtoehtojen hahmottamiseen asiantuntị̧atyössä.

Edellä kuvattu kehityssuunta nostaa uudella tavalla pintaan tutkimuksen, koulutuksen ja kehittämisen väliset vuorovaikutussuhteet ja perinteiset työnjakoratkaisut. Koulutukset muistuttavat yhä useammin tutkimuksellisia prosesseja, joihin osallistuvat sekä koulutuksen osanottajat että kouluttajat.

\section{Ulkopuolisuus voimana - miksi siirtymätiloja tarvitaan?}

Koulutuksellisia siirtymätiloja voidaan verrata Moskovan metodologisen seuran jo vuosikymmeniä ylläpitämiin organisaatioiden toimintapeleihin. (ks. Shtshedrovitskij ym. 1991 ja Schedrovitski 1991). Pelit ovat toimineet suljetussa neuvostoyhteiskunnassa tutkijoiden ylläpitäminä vaihtoehtoisten tulevaisuuksien luomisen kehtona.
Pelejä voidaan verrata neuvostoyhteiskunnasta "irrotetuiksi" soluiksi, joissa tietoisesti kasvatetaan uudenlaisen kulttuurin mahdollisuuksia. Nämä irrotetut solut eli pelit luovat oman pienoistodellisuuden, jossa oikean maailman emotionaaliset ja ajatukselliset prosessit kehittyvät intensiivisessä ja pelkistetyssä muodossa. Pelien aikana tarkastellaan ja ennakoidaan vaihtoehtoisia kehitysnäköaloja sekä kehitellään tulevaisuuden toimintamallien alkioita, joita sitten tulee kasvattaa pelaajien palattua "suureen" todellisuuteen.( Schedrovitski 1991, 31).

Schedrovitski toteaa: "Ymmärsimme, että meidän tulisi koota uudenlainen toimintamalli, joka ylittäisi olemassaolevat sosiaaliset rakenteet. Pelissä piti keskustella siitä, minkä halusimme ilmestyvän myöhemmin. Kysymyksessä oli juuri tulevaisuuteen siirtyminen. Ainoat voimavarat sen toteuttamiseksi olivat osallistujien kehityskyky ja luovuuden potentiaalit". (sama, 29). Työskentelylle on ominaista poikkitieteellinen ongelmakohtaisuus ja tulevaisuuteen projektoiva toimintavaihtoehtojen hahmottaminen.

Peleihin on pyritty tavoittamaan "ihmisiä, jotka ajattelevat toisella tavalla". Tällä he tarkoittavat ihmisiä, jotka kykenevät samanaikaisesti työskentelemään monien vaihtoehtojen kanssa. Ammattilaisten on kyettävä rikkomaan kaavoittunut ajattelutapansa, joka vasta johtaa vuorovaikutuksellisessa prosesseissa syntyviin uusiin ajattelun synteeseihin.

Koulutuksellisten siirtymätilojen ja venäläisten pelien välillä on yhtymäkohtia. Tärkeää on korostaa, että koulutuksellisissa siirtymätiloissa vaihtoa harrastavat työelämän ja tutkimuksen osapuolet tuovat peliin oman alasysteeminsä tavan hahmottaa käsiteltäviä ongelmia. Alkuoletuksen mukaan tilan sisällä käytävien keskustelujen ja vaihdon ansiosta voidaan luoda perustaa oppimiselle, joka ei ole mahdollista oman alasysteemin sisällä. Oppimista luonnehtii pelkistäminen ja keskittyminen ydinkysymyksiin, jotka pitävät sisällään myös tulevaisuuteen projektoivan ajattelun.

Suomalaisessa työelämän todellisuudessa aikuiskoulutukselliset siirtymätilat voivat parhaimmillaan olla hallinnonalojen ja professioiden välille kosketuspintoja luovia keskustelu- ja vuorovaikutusfoorumeita. Niillä on oma tärkeä roolinsa tavoiteltaessa työelämään organisointimalleja, joille on ominaista jatkuva uusiutumiskyky ja liike. 


\section{LÄHTEET}

Arnkil. E. 1990. Sosiaalityö rajasysteemeissä. Sosiaalihallituksen julkaisuja 4/1990. Valtion Painatuskeskus. Helsinki.

Arnkil. E. 1991. Peilejä. Hypoteeseja sosiaalityön ristiriidoista ja kehitysvyöhykkeestä. Sosiaali- ja terveyshallitus, Tutkimuksia 5/1991, Valtion Painatuskeskus, Helsinki.

Crozier M. - Friedberg E. 1980. Actors and Systems, The Politics of Collective Action, The University of Chicago Press.

Filander K, Heiskanen T, Kirjonen J, 1990. Tutkimuksen ja koulutuksen strategiavalinnat työelämän kehittämisessä. Tampereen yliopisto, Työelämän tutkimuskeskuksen julkaisuja, Sarja T 5/1990.

Hirschhorn L. - Gilmore T. N. 1989. The Psychodynamics of a Cultural Change: learnings from a Factory, 211233, Human Resource Management, Summer Volume 28, $\mathrm{nr} 2$, published by John Wiley \& Sons.

Miettinen R. 1990. Koulun muuttamisen mahdollisuudesta. Analyysi opetustyön kehityksestä ja ristiriidoista. Oy Gaudeamus Ab.

Moilanen R. 1990. Koulutuksesta kehitykseen - Johtamiskoulutuksen kehittäminen Action Learning -prosessina. Jyväskylän yliopiston täydennyskoulutuskeskuksen tutkimuksia ja selvityksiä 5/1990.

Morgan G. 1986 Images of Organization, Sage Publications.

Panhelainen Mauri 1991, Korkeakoulujen täydennyskoulutus työorganisaatioiden ja professioiden muutoksessa, julkaisussa Matti Parjanen (toim): Privaatti vai piraatti? Korkeakoulujen aikuiskoulutus käännekohdassaan, Tampereen yliopiston täydennyskoulutuskeskuksen julkaisusarja $A$ 1/91.

Schedrovitski G. 1991. Venäläisten pelien synty ja kehitys, Futura, Tulevaisuuden tutkimuksen seuran jäsenlehti, Vol.10 No 3/1991, 19-31.

Schein E. H. 1987. Organisaatiokulttuuri ja johtaminen, Weiling+Göös.

Shtshedrovitskij G.P - Kotelnikov S.I. 1991. Organisaatio-toimintapeli - uusi tapa järjestää ja kehittää kollektiivista ajatustoimintaa, Yhteiskuntasuunnittelu 1/1991, Yhteiskuntasuunnittelun Seura ry. 29. vuosikerta.

Valkama H. 1991. Muutoksen hallinta koulutusorganisaatiossa. julkaisussa Gröhn T. \& Sava I. (toim.) Kouluyhteisön kehittäminen - menetelmällisiä ja praktisia pohdintoja. Vantaan täydennyskoulutuslaitos, Helsingin yliopisto. 